\title{
C-Reactive Protein As a Triage Test in Guiding Who Should Get a Confirmatory Test For Pulmonary Tuberculosis Diagnosis Among Adults: A Case- Control Proof-of-Concept Study From Urban Tanzania
}

Evarist Chiweka

Ifakara Health Institute

Thomas Maroa

Ifakara Health Institute

Hosiana Temba

Ifakara Health Institute

Joseph Ponera

Ifakara Health Institute

Sharifa Athumani

Ifakara Health Institute

Lujeko Kamwela

Ifakara Health Institute

Mohamed Sasamalo

Ifakara Health Institute

Rastard Naftari

Ifakara Health Institute

Mirambi Tito

Ifakara Health Institute

Francis Mhimbira

Ifakara Health Institute

Jerry Hella ( $\boldsymbol{\nabla}$ jhella@ihi.or.tz)

Ifakara Health Institute

Research Article

Keywords: C-reactive protein, pulmonary tuberculosis, screening

Posted Date: January 5th, 2021 
DOI: https://doi.org/10.21203/rs.3.rs-136689/v1

License: (c) (1) This work is licensed under a Creative Commons Attribution 4.0 International License. Read Full License

Version of Record: A version of this preprint was published at Journal of Tuberculosis Research on January 1st, 2022. See the published version at https://doi.org/10.4236/jtr.2022.101003. 
Word count, inserts and supplemental material:

Abstract 350 words, main text 3586 words

20 


\section{ABSTRACT}

Background: The current screening tools for tuberculosis (TB) are inadequate resulting in insufficient TB case detection and continued community transmission of TB.As the world in geared into finding missing TB cases, new strategies are called for to aid in rapid identification of TB cases. This study aimed to evaluate the role $\mathrm{C}$-reactive protein (CRP)in triaging for who to get a definitive test for active pulmonary TB diagnosis in urban Tanzania.

Methods: A case-control study was conducted among pulmonary TB (PTB) patients and contacts without active PTB. The diagnosis of PTB was performed using GeneXpert MTB/RIF assay and culture. Blood was collected from cases and controls for measuring CRP levels during recruitment. We compared socio-demographic characteristics, clinical and laboratory parameters obtained during recruitment and performed diagnostic accuracy analyses for CRP.

Results: Out of all 193 study participants who were involved in final analysis, 147 (76.2\%) were males. Pulmonary TB cases had significantly lower median BMI than controls (median 17.4 $\mathrm{kg} / \mathrm{m}^{2}$ [IQR: $15.8-19.2 \mathrm{~kg} / \mathrm{m}^{2}$ ] vs., $24.9 \mathrm{~kg} / \mathrm{m}^{2}$ [IQR: $22.1-28.5 \mathrm{~kg} / \mathrm{m}^{2}$ ), $p<0.001$ ). There was no statistical difference in prevalence of HIV between PTB cases and controls i.e., $13.33 \%$ vs., 11.7\%, $p=0.48$. CRP was significantly higher in PTB cases vs., controls (median $67.8 \mathrm{mg} / \mathrm{L}$, [IQR: 36.5- $116.9 \mathrm{mg} / \mathrm{L}]$ vs., $1.55 \mathrm{mg} / \mathrm{L},[\mathrm{IQR}: 0.59-6.0 \mathrm{mg} / \mathrm{L}], p=0.003)$. Furthermore, CRP at cut-off $\geq 10 \mathrm{mg} / \mathrm{L}$ were associated with best combination of sensitivity, specificity and area under the curve of $89.9 \%, 95 \%$ CI: $82.2-95.0,80.9 \%, C I: 71.4-88.2$ and $0.85,95 \%$ CI: $0.80-0.90$ respectively. A multivariate logistic regression model adjusted for fever, night sweats and body mass index showed that CRP above $10 \mathrm{mg} / \mathrm{L}$ was significantly associated with PTB, aOR 5.2, 95\% CI 1.2-22.8. 
44 Conclusions: CRP at cut-off $\geq 10 \mathrm{mg} / \mathrm{L}$ can be used to screen pulmonary TB. These findings can 45 be used to improve TB screening algorithm by incorporating CRP in combination with TB 46 symptoms to identify patients who need further confirmatory TB tests. However, additional 47 prospective studies are required to support our findings and contribute into policy 48 recommendations on use of CRP in a screening algorithm for pulmonary TB.

49 Keywords: C-reactive protein, pulmonary tuberculosis, screening 50 


\section{Background}

Tuberculosis remains one of the world's deadliest communicable diseases. It was estimated that 10 million people fell ill with tuberculosis (TB) and 1.5 million died of the disease globally in 2018 (1). Prompt case detection and subsequent start of effective treatment especially in TB high burden countries is a major strategy for its control (2-5). Systematic screening of individuals presenting to health facilities seeking health care and certain risk groups with high TB prevalence is an important approach to improve early detection of TB.

Symptoms and chest radiography are the available methods to screen for active TB in most resources limited settings while sputum smear microscopy, mycobacterial culture and currently endorsed molecular Xpert MTB/RIF assay (Cepheid, Sunnyvale, Califormia) are confirmation tests (6-8). However, current screening algorithm rely mostly on TB symptoms questionnaire followed by chest radiography - a strategy that is inadequate in TB case detection(9). Furthermore, the rapid and widely used smear microscopy has varied and limited sensitivity while culture is often not available in resource limited setting for routine use (10-12). Therefore, majority of TB patients remain undetected and there is a need for alternative TB diagnostic algorithm especially in TB high burden countries with limited resources.

Inflammatory markers are emerging as tools of choice for TB screening with potentials of being rapid and point of care utility (13). C-reactive protein (CRP) is an acute phase molecule found in plasma whose levels rise significantly in response to tissue damage and infections such as active TB independently of HIV status (14-17). Several observational studies have shown that CRP has association and high sensitivity for the presence of TB (16,18-20). However, despite the evidence shown in the previous observations on the role of CRP as a biomarker for TB, 
performance of screening using CRP has varied across different settings. It is therefore important to determine performance of CRP for screening pulmonary TB in our setting.

We aimed to establish the role of CRP as a screening tool for active pulmonary TB in an observational study of patients with PTB and controls without PTB in urban Tanzania. To address this need, we specifically (i) compared baseline characteristic and distribution of CRP in pulmonary TB cases and controls (ii) determined the discriminatory accuracy of CRP and TB symptoms for pulmonary TB among adults.

\section{Methods}

\section{Study setting}

We included participants from an ongoing prospective cohort of bacteriological confirmed pulmonary TB patients in Tanzania (TB-DAR) initiated in October 2013. The study site is in Temeke district of Dar es Salaam, the economic capital of Tanzania. Dar es Salaam has approximately 4.4 million people and notifying $22 \%$ of all TB cases in Tanzania(21). Participants included were sputum smear-positive adult TB patients (TB cases) and household contacts (controls) that did not have active disease ( $\geq 18$ years).

\section{Selection of study participants}

Among 359 TB patients recruited between 2014 and 2015, we randomly selected 103 TB cases and 103 household contacts exposed to a TB cases but without active disease (controls). The final analysis was restricted to 193 participants i.e., 99 (51.3\%) TB cases and 94 controls with serum CRP and sputum samples examination results.

\section{Study procedures and data collection}


All participants recruited were clinically evaluated during recruitment as either TB cases or controls after ruling out presence of active TB among controls. Socio-demographic data, clinical data and biological samples were collected at the time of recruitment. Briefly, data were captured using the OpenDataKit application (www.opendatakit.org) on Android tablets, and data quality was monitored in real-time using the odk_planner tool (22). Serum samples were taken at the time of TB diagnosis before starting TB treatment (pulmonary TB cases) or at the time of recruitment (controls) and stored at $-80^{\circ} \mathrm{C}$. GeneXpert MTB/RIF assay was used to rule out TB in controls. During recruitment, we collected urine and stool for diagnosis of helminths infections as well as nasopharyngeal swabs (Copan, USA) to detect respiratory viruses and bacteria.

\section{Laboratory procedures}

We used extensive laboratory techniques to evaluate the presence of various soil transmitted helminths from urine and stool samples. Kato-Katz method (in triplicates), Baermann technique (in duplicates), urine filtration (in duplicates), and circulating cathodic rapid antigen test (POCCCA; Rapid Medical Diagnostics, South Africa) were used to diagnose helminths (Strongyloides stercoralis, Trichuris trichiura, Schistosoma mansoni, Schistosoma haematobium, Ascaris lumbricoides).

Sputum samples from TB cases and controls were collected and stored at $4^{\circ}$ Celsius and transported in temperature-controlled cool boxes to a biosafety level 2+ laboratory at Bagamoyo Research and Training Center, IHI. Specimens were homogenized and decontaminated using $N$ acetyl L-cysteine Sodium Hydroxide and then incubated according to standard procedures on Löwenstein-Jensen medium and read once each week until there is Mycobacterium tuberculosis 
(Mtb) growth otherwise they were declared as negative after 8 weeks. In case of Mtb growth, the isolate was subject to a Capilia TB/MPT64 antigen test to confirm the presence of mycobacterium tuberculosis complex species.

Nasopharyngeal swabs were analysed to detect presence of respiratory pathogens using a multiplex real-time PCR with a broad panel of 16 viral (Anyplex II RV16) and seven bacterial (Allplex panel 4) respiratory pathogens (Table 1) according to the manufacturer's instructions (Seegene, Seoul, South Korea).

Haematological tests were performed immediately after sample collection when possible while those tests which needed specialized laboratory and not available within the country were stored at $-80^{\circ} \mathrm{C}$ until shipping them abroad. HIV screening was done using Alere Determine HIV rapid test, and the Uni-gold HIV (Trinity Biotech, USA) rapid test served as a confirmatory test in case of a positive screening test. Full blood counts were done with a MS4 Vet haematology analyser (Diamond Diagnostics, Massachusetts, USA) at the Temeke Regional Referral Hospital laboratory. CRP analysis was performed at the Labor Risch, Bern (Switzerland) using the Siemens Nephelometer BN II (soluble transferrin receptor) and the Cobas 6000, Roche diagnostics, Switzerland. Lastly we confirm that all methods were carried out in accordance with relevant guidelines and regulations.

Table 1: Detection of respiratory viral and bacterial pathogens using a multiplex real-time PCR in nasopharyngeal swabs

\begin{tabular}{|l|l|}
\hline Viral species- Anyplex II RV16 (panels A and B) & Bacterial species - Allplex respiratory panel 4 \\
\hline Adenovirus & Mycoplasma pneumonia \\
\hline
\end{tabular}




\begin{tabular}{|l|l|}
\hline Influenza A/B & Chlamydophila pneumonia \\
\hline Rhinovirus A/B/C & Legionella pneumophila \\
\hline Respiratory syncytial virus A/B & Haemophilus influenza \\
\hline Parainfluenza virus 1/2/3/4 & Streptococcus pneumoniae \\
\hline Bocavirus 1/2/3/4 & Bordetella pertussis \\
\hline Metapneumovirus & Bordetella parapertussis \\
\hline Coronavirus 229 & \\
\hline Coronavirus OC4 & \\
\hline Coronavirus NL63 & \\
\hline Enterovirus & \\
\hline
\end{tabular}

\section{Definitions of terms}

We used at CRP concentration cut-off $\geq 10 \mathrm{mg} / \mathrm{L}$ to indicate presence of active TB vs., $<10 \mathrm{mg} / \mathrm{L}$ indicated absence of active TB (23). Helminths infection was defined as infection with any helminth species, and respiratory infection as detection of any respiratory viral or bacterial pathogen. We classify TB symptoms as the presence of fever, weight loss, night sweats and fever. We used $\mathrm{BMI} \leq 18.5 \mathrm{~kg} / \mathrm{m}^{2}$ as underweight.

\section{Statistical analysis}

Socio-demographic characteristics, clinical and laboratory parameters of pulmonary TB cases and controls were compared for data obtained during recruitment. Wilcoxon rank-sum test or Student's $t$-tests were used for continuous variables while chi-square or Fisher's exact tests for comparison of categorical variables. CRP concentrations for pulmonary TB cases discrimination were explored using sensitivity, specificity and receiver operating characteristic curves. We used 
147 odds ratios and 95\% confidence interval associated with CRP cut-offs concentration and TB

148 symptoms to determine their role in predicting pulmonary $\mathrm{TB}$ cases using univariate and 149 multivariable logistic regression analyses. All statistical tests were two-sided, and we set 150 threshold of a statistically significant difference at an alpha level of 0.05 . We performed all 151 analyses using Stata version 15.1 (Stata corporation, Texas, USA).

\section{Ethical considerations}

153 The study was approved by the institutional review board of Ifakara Health Institute (IHI, 154 reference no. IHI/IRB/04-2015), the Medical Research Coordinating Committee of the National 155 Institute for Medical Research in Tanzania (NIMR, reference no. NIMR/HQ/R.8c/Vol. I/357), 156 and the Ethics Committee of the Canton of Basel (EKNZ, reference no. UBE-15/42). All 157 participants gave written informed consent before enrolment. 


\section{Results}

\section{Socio-demographic and clinical characteristics}

The median age was 32.7 years (interquartile range [IQR] 26.5-40.0); and 147 (76.2\%) were males out of all 193 study participants who were involved in final analysis. Overall, the median body mass index (BMI) at the time of recruitment was $20.1 \mathrm{~kg} / \mathrm{m}^{2}$, IQR $17.3-25.1 \mathrm{~kg} / \mathrm{m}^{2}$. Pulmonary TB cases had significantly lower median BMI than recruited controls (median 17.4 $\mathrm{kg} / \mathrm{m}^{2}$ [IQR: $15.8-19.2 \mathrm{~kg} / \mathrm{m}^{2}$ ] vs., $24.9 \mathrm{~kg} / \mathrm{m}^{2}$ [IQR: $22.1-28.5 \mathrm{~kg} / \mathrm{m}^{2}$ ], $p<0.001$ ) (Table 2).

The prevalence of HIV infection among study participants was $12.44 \%$, with no statistical difference in prevalence of HIV infection between pulmonary TB cases and controls i.e., $13.33 \%$ vs., $11.7 \%, p=0.48$. We found a higher prevalence of helminths infections among pulmonary TB cases than controls i.e., $32.2 \%$ vs., $21.28 \%$, however this difference in prevalence between the two study groups were not statistically significant different. Strongyloides stercoralis contributed more into the burden of soil transmitted helminths among pulmonary TB cases than controls i.e., 22.22\% vs., $9.57 \%, p=0.019$. Pulmonary TB cases recruited in our study reported classical TB symptoms more frequently than controls with cough and weight loss experienced by all cases, $p<0.001$ (Table 2).

\section{Haematological parameters and acute phase proteins}

The overall median CRP concentration was $18.7 \mathrm{mg} / \mathrm{L}$ (IQR: $1.4-80 \mathrm{mg} / \mathrm{L}$ ) where this biomarker was significantly higher in pulmonary TB cases compared to controls (median $67.8 \mathrm{mg} / \mathrm{L}$, [IQR: 36.5- $116.9 \mathrm{mg} / \mathrm{L}]$ vs., $1.55 \mathrm{mg} / \mathrm{L}$, [IQR: $0.59-6.0 \mathrm{mg} / \mathrm{L}], p=0.003)$. CRP when used at a cut-off of $\geq 10 \mathrm{mg} / \mathrm{L}$ could statistically differentiate active TB vs., no active TB disease among adults recruited (Table3). Similarly, the average haemoglobin $(\mathrm{Hb})$ level was $12.3 \mathrm{mg} / \mathrm{dL} \pm 2.18 \mathrm{mg} / \mathrm{dL}$ 
180 and we found that pulmonary TB cases were more likely to have lower average Hb levels than 181 controls (mean $11.8 \mathrm{mg} / \mathrm{mL} \pm 2.1 \mathrm{mg} / \mathrm{dL}$ vs., $12.8 \mathrm{mg} / \mathrm{mL} \pm 2.1 p=0.001$ ). Serum ferritin levels 182 were higher in TB cases than in controls (median $355.5 \mu \mathrm{g} / \mathrm{L}$ vs., $103.5 \mu \mathrm{g} / \mathrm{L}, \mathrm{p}<0.001$ ).

183 Furthermore, serum albumin levels at the time of pulmonary TB diagnosis and recruitment of 184 controls was significantly lower among TB cases than among controls (mean $28.58 \pm 6.14 \mathrm{~g} / \mathrm{L}$ 185 vs., $39.25 \pm 5.54 \mathrm{~g} / \mathrm{L}, p<0.001$, see Table 3 ). 
Table 2: Performance characteristics of different CRP cut-offs for pulmonary TB discrimination among adults at Temeke, Dar es Salaam

\begin{tabular}{|c|c|c|c|c|c|}
\hline $\begin{array}{l}\text { Cut point } \\
\text { mg/dl }\end{array}$ & $\begin{array}{l}\text { Sensitivity, } \\
(95 \% \text { CI })\end{array}$ & $\begin{array}{l}\text { Specificity, } \\
(95 \% \text { CI })\end{array}$ & $\begin{array}{l}\text { PPV, } \\
(95 \% \mathrm{CI})\end{array}$ & $\begin{array}{l}\text { NPV, } \\
(95 \% \mathrm{CI})\end{array}$ & $\begin{array}{l}\text { AUC, } \\
(95 \% \text { CI })\end{array}$ \\
\hline $5 \mathrm{mg} / \mathrm{L}$ & $93.9 \%,(87.3-97.7)$ & $69.1 \%,(58.8-78.3)$ & $76.2 \%,(67.7-83.5)$ & $91.5 \%,(82.5-96.8)$ & $0.815,(0.763-0.868)$ \\
\hline $10 \mathrm{mg} / \mathrm{L}$ & $89.9 \%,(82.2-95.0)$ & $80.9 \%,(71.4-88.2)$ & $83.2 \%,(74.7-89.7)$ & $88.4 \%,(79.7-94.3)$ & $0.854,(0.804-0.904)$ \\
\hline $15 \mathrm{mg} / \mathrm{L}$ & $86.9 \%,(78.6-92.8)$ & $85.1 \%,(76.3-91.6)$ & $86.0 \%,(77.6-92.1)$ & $86.0 \%,(77.3-92.3)$ & $0.859,(0.811-0.909)$ \\
\hline $20 \mathrm{mg} / \mathrm{L}$ & $85.9 \%,(77.4-92.0)$ & $89.4 \%,(81.3-94.8)$ & $89.5 \%,(81.5-94.8)$ & $85.7 \%,(77.2-92)$ & $0.876,(0.829-0.923)$ \\
\hline $25 \mathrm{mg} / \mathrm{L}$ & $84.8 \%,(76.2-91.3)$ & $89.4 \%,(81.3-94.8)$ & $89.4 \%,(81.3-94.8)$ & $84.8 \%,(76.2-91.3)$ & $0.871,(0.824-0.918)$ \\
\hline
\end{tabular}


191

192

We evaluated the utility of different CRP cut-offs in discriminating cases of pulmonary TB using gradual increasing of concentration from $5 \mathrm{mg} / \mathrm{L}$ to $25 \mathrm{mg} / \mathrm{L}$. CRP at cut-off $\geq 5 \mathrm{mg} / \mathrm{L}$ were associated with sensitivity, specificity, and AUC of 93.9\%, 95\% CI: (87.3-97.7), 69.1\%, 95\% CI: (58.8-78.3) and 0.82, 95\% CI: (0.76-0.87) respectively. Increasing CRP cut-off $\geq 10 \mathrm{mg} / \mathrm{L}$ were associated with sensitivity, specificity and AUC of $89.9 \%, 95 \%$ CI: (82.2-95.0), $80.9 \%$, CI: (71.4-88.2) and 0.85, 95\%CI: (0.80-0.90) respectively. CRP cut-offs values of $\geq 15 \mathrm{mg} / \mathrm{L}$, 20mg/L and 25mg/L were associated with increasing specificity and AUC. However, they gradually compromise their sensitivity (Table 4 and Figure 1). In univariate logistic regression analysis underweight, night sweats, fever and $\mathrm{CRP} \geq 10 \mathrm{mg} / \mathrm{L}$ were significantly associated with pulmonary TB cases (OR for underweight 15.3, 95\% CI: 5.9 - 39.8; OR for night sweats 218.7, 95\% CI: 59.7 - 801.6; OR for fever 85.2, 95\% CI: 30.0 - 241.3; OR for CRP $\geq 10 \mathrm{mg} / \mathrm{L} 37.6$, 95\% CI: 16.4 - 86.3).In multivariable logistic regression all symptoms remained independently significantly associated with pulmonary $\mathrm{TB}$ cases (aOR for underweight 9.2, 95\% CI: 1.4 61.5;aOR for night sweats 9.7, 95\% CI: 1.9 - 49.9; aOR for fever 85.2, 95\% CI: 30.0 241.3;aOR for $\mathrm{CRP} \geq 10 \mathrm{mg} / \mathrm{L} 5.2,95 \% \mathrm{CI}: 1.2-22.8$ ) (see figure $2 \& 3$ ). 


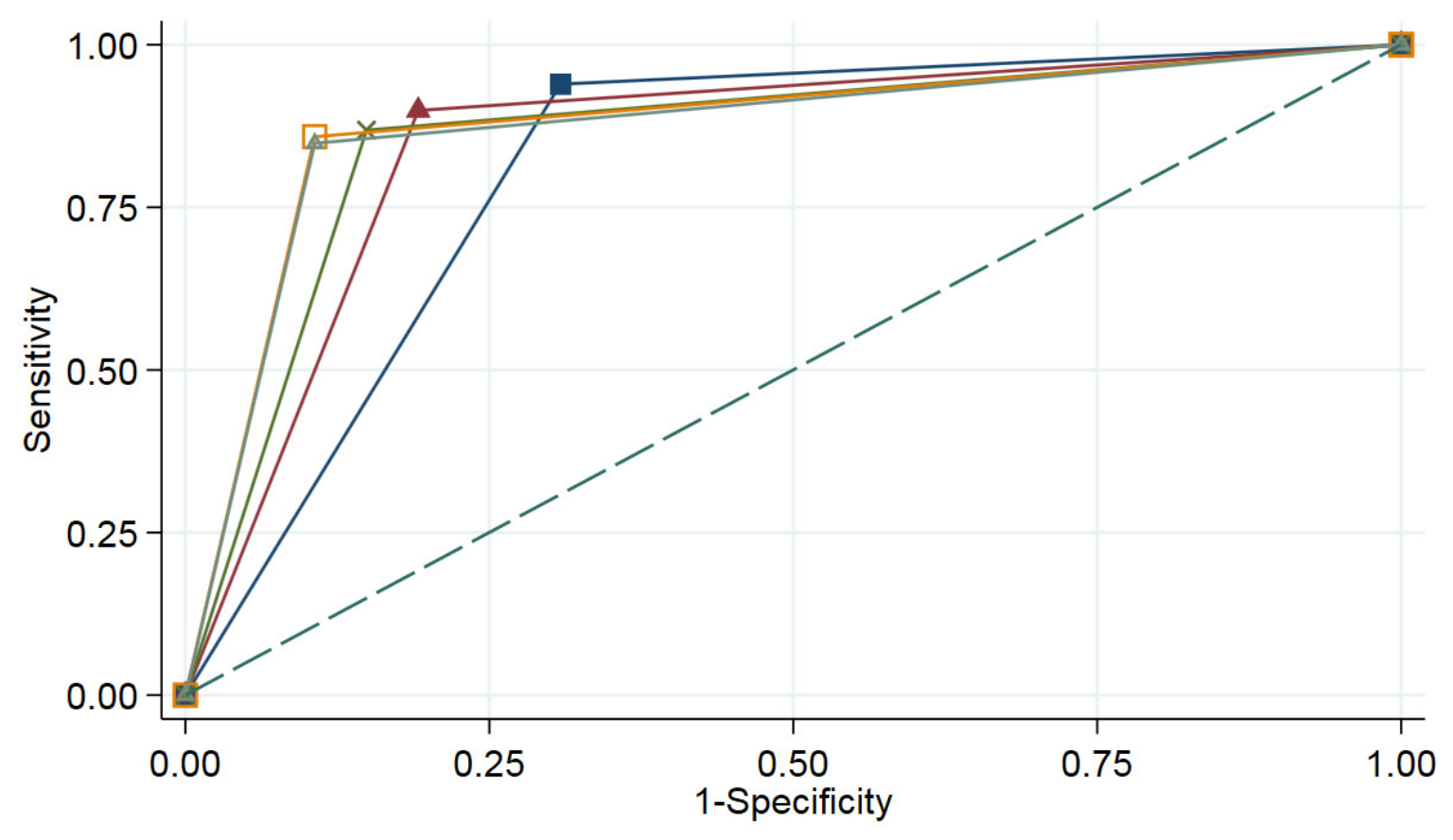

Figure 1: Receiver operator characteristic (ROC) curves for different CRP cut-offs for TB diagnosis among adults in Temeke, Dar es Salaam. 


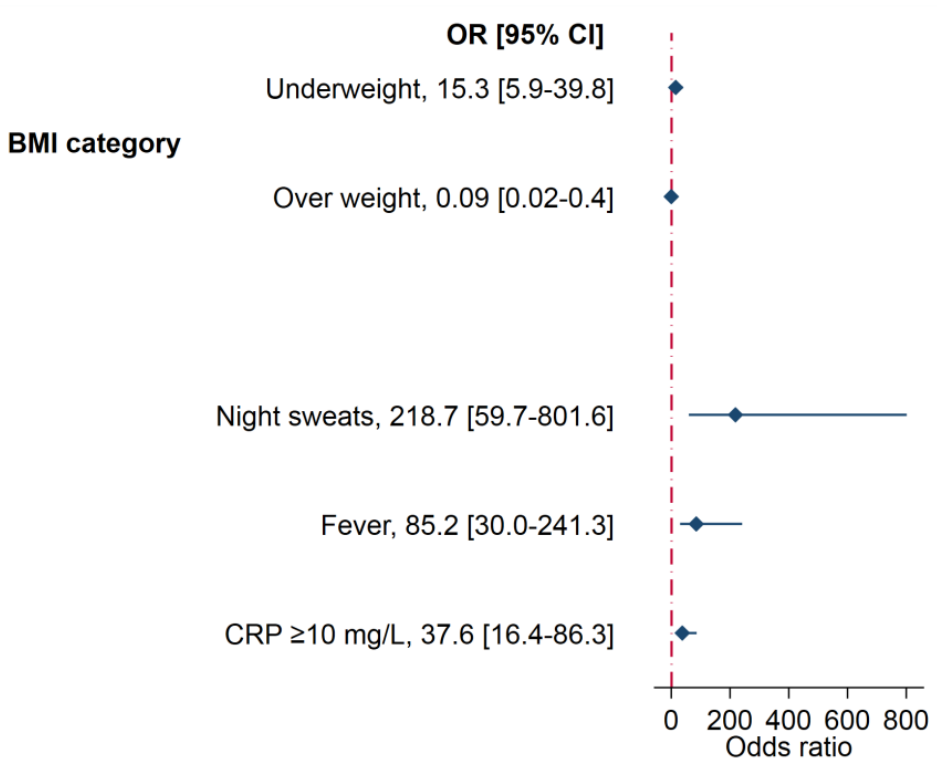

Figure 2: Univariate logistic regression analyses for CRP cut-off $\geq 10 \mathrm{mg} / \mathrm{L}$ and pulmonary

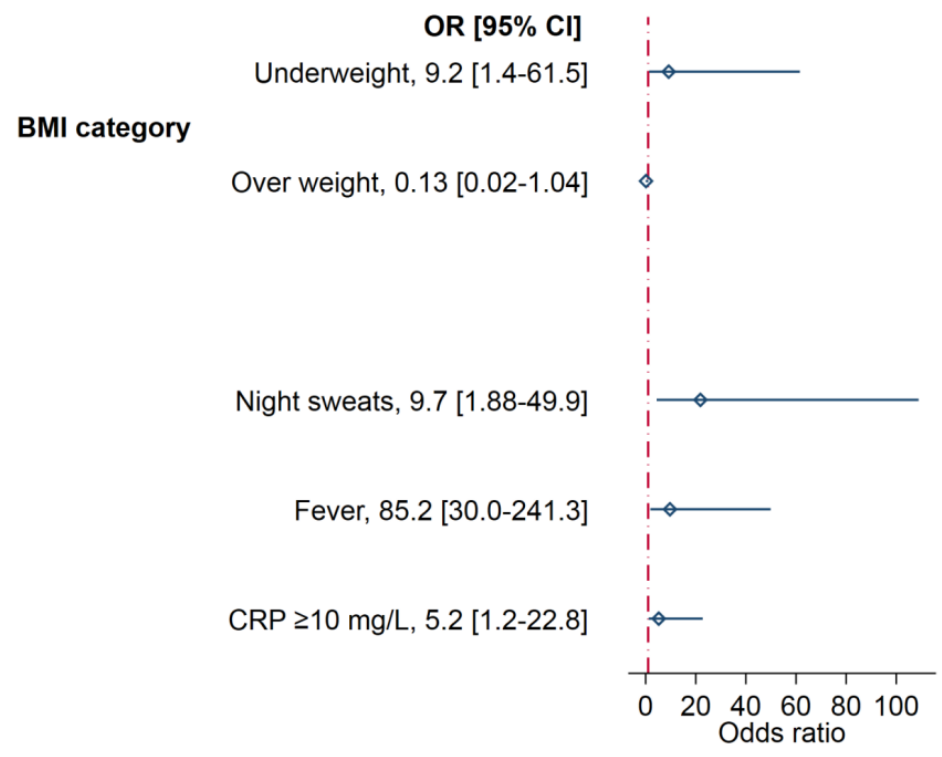

214 Figure 3: Multivariate logistic regression analyses for $\mathrm{CRP}$ cut-off $\geq 10 \mathrm{mg} / \mathrm{L}$ and $\mathrm{TB}$ 


\section{Discussion}

In this observational study of adult pulmonary TB cases and controls in urban Tanzania, we determined screening performance of CRP for pulmonary TB. We found that CRP at concentration cut-off $\geq 10 \mathrm{mg} / \mathrm{L}$ was associated with best combination of sensitivity, specificity and AUC for discriminating pulmonary TB cases. We also demonstrated that classical TB symptoms and CRP concentration cut-off $\geq 10 \mathrm{mg} / \mathrm{L}$ can accurately predict pulmonary TB cases. These findings are of clinical relevant because CRP can be easily measured and utilized at point of care (24). Furthermore, night sweats, fever and nutritional status are routinely sought by clinicians when evaluating patients.

The findings on performance of CRP on identifying pulmonary TB cases are in agreements with other findings elsewhere. Lawn and his colleagues in South Africa demonstrated a CRP of $10 \mathrm{mg} / \mathrm{L}$ and above have a relatively high sensitivity of $85.2 \%$ and reliably rule out active PTB (25). However, their finding applies only to half of their study population. Another study in the same country revealed any elevated CRP with confirmed TB can be useful for ruling out TB at NPV of $0.72-0.96$ (26). However, raised CRP might have been caused by other diseases processes, notably intestinal parasites and respiratory infection $(27,28)$. Thus, other diseases should be considered and looked for in a patient with significantly raised CRP levels. In the present study we addressed the impact of helminthiasis and respiratory infections on serum levels of CRP. We found no statistically significant differences in frequencies of their distribution in the two groups. These findings were in contrary to observations from other studies. Studies in Tanzania and Ethiopia demonstrated high co-existence of pulmonary TB and helminthiasis $(29,30)$. It was known that both diseases have impact on cellular mediated immunity and influence the natural course of one another (30-32). However, similar prevalence 
in present study could be partially explained by several factors. First, our study setting is urban which is characterized by low exposure to worms and high literacy associated with frequent practice of de-worming. Second, our study participants were recruited from same environment. Last, our two groups have equal distribution of socio-demographic characteristics, which are important determinants of helminthiasis $(33,34)$. A major difference in our study was a similar proportion of HIV infection in cases and controls, i.e., $13.13 \%$ vs $11.7 \%$. This is in disagreement with the fact that the two diseases are closely related. Previous studies in pulmonary TB have reported higher rates of HIV infection and patterns of co-existence were described in many places. Studies in Tanzania observed high prevalence of TB-HIV co-infection $(35,36)$. Similar observations of high prevalence were demonstrated in India $(37,38)$. Meta- analysis of studies done in Sub-Saharan Africa demonstrated a very high prevalence (34.4\%) of HIV infection among pulmonary TB patients (39). However, overall prevalence of HIV in our study population is higher than Tanzanian general population (40). The similar distribution in HIV prevalence between pulmonary TB cases and controls can be partly explained by overly selection of study participants of a case - control study design.

Importantly, data from our study demonstrated that using CRP at cut-off $\geq 10 \mathrm{mg} / \mathrm{L}$ were associated with excellent combination of sensitivity, specificity and AUC for discriminating pulmonary TB cases, while higher cut-off values are associated with increasing specificity and AUC in expenses of sensitivity thus, compromising ability to discriminate pulmonary TB cases. Thus, CRP cut-off value $\geq 10 \mathrm{mg} / \mathrm{L}$ will reliably discriminate pulmonary TB from a vast majority of TB suspects in high TB burden settings. The demonstrated relatively high sensitivity and specificity of $89.9 \%$ and $80.9 \%$ respectively at $\mathrm{CRP}$ concentration of $\geq 10 \mathrm{mg} / \mathrm{L}$ is superior to varied low sensitivity of sputum smear microscopy ranging 20-80\% (41). Again, data from our study demonstrated that classical pulmonary TB symptoms and CRP at cut-off $\geq 10 \mathrm{mg} / \mathrm{L}$ were 
significantly more associated with pulmonary TB cases than controls. The observed association between pulmonary TB and classical TB symptoms has been described by other groups. In Kenya, $75 \%, 100 \%$ and $83 \%$ of pulmonary TB cases reported fever, night sweats and weight loss respectively, while in South Africa $78 \%, 78 \%$ and $100 \%$ reported the symptoms respectively (42). One group in TB high burden country, China reported that TB symptoms were found in $75.8 \%$ of cases (43). However, symptoms alone have been shown to be less reliable for pulmonary TB especially in areas with high prevalence of TB-HIV co-infection. The relationship between pulmonary TB and nutritional status is known for years. Underweight is a wellrecognized risk factor for pulmonary TB and pulmonary TB can lead to underweight. Night sweats and fever are non-specific symptom of TB and are constitutional symptoms of many disease processes. Therefore, data from our study are informing CRP at cut-off $\geq 10 \mathrm{mg} / \mathrm{L}$, underweight, night sweats and fever scan be used for screening pulmonary TB in high burden settings.

In spite of the findings of this study, there are limitations which need to be addressed. First, we could not exclude all possible disease processes that might be responsible for rise in CRP. Second, we are not able to perform stratified analysis base on disease severity. Third, the study was done in urban setting where the patient population might differ from other rural primary care settings. Finally, the case-control study design associated with overly selection of participants can explain the limitations observed on role of CRP and classical TB symptoms to screen pulmonary TB case.

In conclusion, this study has demonstrated that CRP is a potential tool for discriminating pulmonary TB in adults. Furthermore, CRP at cut-off $\geq 10 \mathrm{mg} / \mathrm{l}$ and classical pulmonary TB symptoms can be used systematically to screen pulmonary TB among suspects. The findings can 
therefore be used to improve TB screening algorithm by incorporating CRP concentration of $\geq$

$28710 \mathrm{mg} / \mathrm{L}$ in combination with classical TB symptoms to identify patients who need further TB 288 work out or empirical treatment. This approach can add significantly in reduction of TB burden.

289 However, additional well-designed large-scale studies are required in setting of intended use to 290 estimates the role of CRP and TB symptoms for pulmonary TB screening to support policy 291 recommendations. Furthermore, studies are required to determine appropriate strategy of 292 screening algorithm for pulmonary TB using CRP and TB symptoms. 
294 aOR

295 AUC

296 BMI

297

CI

298 CRP

$299 \mathrm{Hb}$

300 HIV

$301 \quad$ IHI

302

303

IRB

304

MTB

$305 \quad$ NIMR

306 NPV

307 OR

308

POC CCA

309 PPV

310

Adjusted odds ratio

Area under the curve

Body mass index

Confidence interval

C-reactive protein

Haemoglobin

Human immune deficiency virus

Ifakara Health Institute

Inter quartile range

Institutional Review Body

Mycobacterium tuberculosis

National Institute for Medical Research

Negative predictive value

Odds ratio

Point of care - Circulating Cathodic Antigen

Positive predictive value

Rifampicin 
311 ROC

312

TB

313

USA
Receiver operating characteristic

Tuberculosis

314

United States of America 


\section{Declarations}

\section{Ethics approval and consent to participate}

317 The study was approved by the institutional review board of the Ifakara Health Institute (IHI;

318 reference no. IHI/IRB/04-2015) and the Medical Research Coordinating Committee of the

319 National Institute of Medical Research in Tanzania (NIMR; reference no. NIMR/HQ/R.8c/Vol.

320 I/357). All study participants gave written informed consent before enrolment into the study.

\section{Consent for publication}

322 Not applicable.

\section{Availability of data and material}

The datasets that were used for analysis and preparation of this manuscript are not publicly available due the national policy on data sharing. The datasets will be available from the corresponding author upon reasonable request where concerned parties will sign a data transfer agreement approved by the Medical Research Coordinating Committee.

\section{Competing interest}

329 The authors declare that they have no competing interests.

\section{Funding}

This work was supported by funding from the Rudolf Geigy Foundation (Basel, Switzerland). 
333 Conceived and designed the study: EC, LK, MS, TM, HT, FM and JH. EC, MS, FM, and $334 \mathrm{JH}$ analyzed the data. TM, HT, JP, SA, RN and MT contributed clinical data. MS, LK, RJ, 335 JP and MT contributed laboratory data. EC, FM and JH prepared the first draft of the 336 manuscript. All authors contributed in final manuscript revisions and approved the final 337 version.

\section{Acknowledgements}

339 We thank all study participants for participating in this study. We are grateful to the Temeke

340 Regional Referral Hospital, as well as the District and Regional tuberculosis coordinators from 341 the National Tuberculosis and Leprosy Programme. 


\section{References}

344 1. World Health Organization. Global tuberculosis report. 2019.

2. Lönnroth K, Castro KG, Chakaya JM, Chauhan LS, Floyd K, Glaziou P, et al. Tuberculosis control and elimination 2010-50: cure, care, and social development. Lancet. 2010;375(9728):1814-29.

3. Teo AKJ, Singh SR, Prem K, Hsu LY, Yi S. Delayed diagnosis and treatment of pulmonary tuberculosis in high-burden countries: A systematic review protocol. BMJ Open. 2019;9(7):1-4.

4. Theron G, Peter J, Dowdy D, Langley I, Squire SB, Dheda K. Do high rates of empirical treatment undermine the potential effect of new diagnostic tests for tuberculosis in highburden settings? Vol. 14, The Lancet Infectious Diseases. Elsevier Ltd; 2014. p. 527-32.

5. Hanrahan CF, Selibas K, Deery CB, Dansey H, Clouse K, Bassett J, et al. Time to Treatment and Patient Outcomes among TB Suspects Screened by a Single Point-of-Care Xpert MTB/RIF at a Primary Care Clinic in Johannesburg, South Africa. PLoS One. $2013 ; 8(6)$.

6. van't Hoog AH, Langendam M, Mitchell E, Cobelens FG, Sinclair D, Leeflang MMG, et al. Symptom- and chest-radiography screening for active pulmonary tuberculosis in HIVnegative adults and adults with unknown HIV status. Cochrane Database Syst Rev. 2014;2014(1).

7. Boehme CC, Nicol MP, Nabeta P, Michael JS, Gotuzzo E, Tahirli R, et al. Feasibility, diagnostic accuracy, and effectiveness of decentralised use of the Xpert MTB/RIF test for 
diagnosis of tuberculosis and multidrug resistance: A multicentre implementation study. Lancet. 2011;377(9776):1495-505.

8. Dunn JJ, Starke JR, Revell PA. Laboratory diagnosis of mycobacterium tuberculosis infection and disease in children. J Clin Microbiol. 2016;54(6):1434-41.

9. Van't Hoog AH, Laserson KF, Githui WA, Meme HK, Agaya JA, Odeny LO, et al. High prevalence of pulmonary tuberculosis and inadequate case finding in rural Western Kenya. Am J Respir Crit Care Med. 2011;183(9):1245-53.

10. Weyer K, Carai S, Nunn P. Viewpoint TB diagnostics: What does the world really need? J Infect Dis. 2011;204(SUPPL. 4).

11. Sharma SK, Kohli M, Yadav RN, Chaubey J, Bhasin D, Sreenivas V, et al. Evaluating the diagnostic accuracy of xpert MTB/RIF assay in pulmonary tuberculosis. PLoS One. 2015;10(10):132-40.

12. Dheda K, Ruhwald M, Theron G, Peter J, Yam WC. Point-of-care diagnosis of tuberculosis: Past, present and future. Vol. 18, Respirology. 2013. p. 217-32.

13. Polzin A, Pletz M, Erbes R, Raffenberg M, Mauch H, Wagner S, et al. Procalcitonin as a diagnostic tool in lower respiratory tract infections and tuberculosis. Eur Respir J. 2003;21(6):939-43.

14. Black S, Kushner I, Samols D. C-reactive protein. J Biol Chem. 2004;279(47):48487-90.

15. El-Shafey B, Bahr H, Ganna S, Attia M, Rakhawy M. The diagnostic value of serum levels of C-reactive protein and procalcitonin in differentiation between active pulmonary TB and CAP. Egypt J Bronchol. 2015;9(2):178. 
16. Skogmar S, Schön T, Balcha TT, Sturegård E, Jansson M, Björkman P. Plasma Levels of Neopterin and C-Reactive Protein (CRP) in Tuberculosis (TB) with and without HIV Coinfection in Relation to CD4 Cell Count. PLoS One. 2015;10(12):1-12.

17. Lawn SD, Obeng J, Acheampong JW, Griffin GE. Resolution of the acute-phase response in west african patients receiving treatment for pulmonary tuberculosis. Int $\mathbf{J}$ Tuberc Lung Dis. 2000;4(4):340-4.

18. Mesquita EDD, Gil-Santana L, Ramalho D, Tonomura E, Silva EC, Oliveira MM, et al. Associations between systemic inflammation, mycobacterial loads in sputum and radiological improvement after treatment initiation in pulmonary TB patients from Brazil: a prospective cohort study. 2016;

19. Drain PK, Mayeza L, Bartman P, Hurtado R, Moodley P, Varghese S, et al. Diagnostic accuracy and clinical role of rapid C-reactive protein testing in HIV-infected individuals with presumed tuberculosis in South Africa. Int J Tuberc Lung Dis. 2014 Jan 1;18(1):20_ 6.

20. Lawn SD, Wiktor S, Coulibaly D, Ackah AN, Lal RB. Serum C-reactive protein and detection of tuberculosis in persons co-infected with the human immunodeficiency virus. Trans R Soc Trop Med Hyg. 2001;95(1):41-2.

21. Ministry of Health Community Development, Gender E and C. The National Tuberculosis and Leprosy 2018 Annual Report. 2018. 2018.

22. Steiner A, Hella J, Grüninger S, Mhalu G, Mhimbira F, Cercamondi CI, et al. Managing research and surveillance projects in real-time with a novel open-source eManagement tool designed for under-resourced countries. J Am Med Informatics Assoc. 
23. Yoon C, Semitala FC, Atuhumuza E, Katende J, Mwebe S, Asege L, et al. Point-of-care C-reactive protein-based tuberculosis screening for people living with HIV: a diagnostic accuracy study. Lancet Infect Dis. 2017;17(12):1285-92.

24. Ward C. Point-of-care C-reactive protein testing to optimise antibiotic use in a primary care urgent care centre setting. BMJ Open Qual. 2018;7(4).

25. Lawn SD, Kerkhoff AD, Vogt M, Wood R. Diagnostic and prognostic value of serum Creactive protein for screening for HIV-associated tuberculosis. Int J Tuberc Lung Dis. 2013;17(5):636-43.

26. Wilson D, Badri M, Maartens G. Performance of Serum C-Reactive Protein as a Screening Test for Smear-Negative Tuberculosis in an Ambulatory High HIV Prevalence Population. PLoS One. 2011;

27. Harrison M. Erythrocyte sedimentation rate and C-reactive protein. Aust Prescr. 2015;38(3):93-4.

28. Sbong S, Feldman M. Frequency and causes of C-reactive protein and erythrocyte sedimentation rate disagreements in adults. Int J Rheum Dis. 2015;18(1):29-32.

29. Mhimbira F, Hella J, Said K, Kamwela L, Sasamalo M, Maroa T, et al. Prevalence and clinical relevance of helminth co-infections among tuberculosis patients in urban Tanzania. PLoS Negl Trop Dis. 2017;11(2):1-19.

30. Alemu A, Kebede A, Dagne B, Amare M, Diriba G, Yenew B, et al. Intestinal parasites co-infection and associated factors among active pulmonary tuberculosis patients in 
selected health centers, Addis Ababa, Ethiopia: Unmatched case control study. BMC Infect Dis. 2019;19(1):1-10.

31. Elias D, Mengistu G, Akuffo H, Britton S. Are intestinal helminths risk factors for developing active tuberculosis? Trop Med Int Heal. 2006;11(4):551-8.

32. George PJ, Kumar NP, Sridhar R, Hanna LE, Nair D, Banurekha V V., et al. Coincident Helminth Infection Modulates Systemic Inflammation and Immune Activation in Active Pulmonary Tuberculosis. PLoS Negl Trop Dis. 2014;8(11).

33. Id AM, Sofian SM, Shaari SA, Hoh B, Lim YA. Prevalence, intensity and associated risk factors of soil transmitted helminth infections : A comparison between Negritos ( indigenous ) in inland jungle and those in resettlement at town peripheries. PLoS Negl Trop Dis. 2019;1-22.

34. Hotez PJ. Aboriginal Populations and Their Neglected Tropical Diseases. PLoS Negl Trop Dis. 2014;8(1):1-4.

35. Gunda DW, Maganga SC, Nkandala I, Kilonzo SB, Mpondo BC, Shao ER, et al. Prevalence and risk factors of active TB among Adult HIV Patients Receiving ART in Northwestern Tanzania: A Retrospective Cohort Study. Can J Infect Dis Med Microbiol. $2018 ; 2018$.

36. Ngowi BJ, Mfinanga SG, Bruun JN, Morkve O. Pulmonary tuberculosis among people living with HIV/AIDS attending care and treatment in rural northern Tanzania. BMC Public Health. 2008;8:2-8.

37. Manjareeka M, Nanda S. Prevalence of HIV infection among tuberculosis patients in 
Eastern India. J Infect Public Health. 2013;6(5):358-62.

450

451

452

453

454

455

456

457

458

459

460

461

462

463

464

465

466

467

38. Giri PA, Deshpande JD, Phalke DB. Prevalence of pulmonary tuberculosis among HIV positive patients attending antiretroviral therapy clinic. N Am J Med Sci. 2013;5(6):36770.

39. Gelaw YA, Williams G, Soares Magalhães RJ, Gilks CF, Assefa Y. HIV Prevalence Among Tuberculosis Patients in Sub-Saharan Africa: A Systematic Review and Metaanalysis. AIDS Behav. 2019;23(6):1561-75.

40. TACAIDS. Tanzania HIV Impact Survey. 2016.

41. Steingart KR, Ng V, Henry M, Hopewell PC, Ramsay A, Cunningham J, et al. Sputum processing methods to improve the sensitivity of smear microscopy for tuberculosis : a systematic review. Lancet Infect Dis. 2006;6(October).

42. Brennan A, Maskew M, Larson BA, Tsikhutsu I, Bii M, Vezi L, et al. Prevalence of TB symptoms, diagnosis and treatment among people living with HIV (PLHIV) not on ART presenting at outpatient clinics in South Africa and Kenya: Baseline results from a clinical trial. BMJ Open. 2020;10(9):1-10.

43. Chen JO, Qiu YB, Rueda ZV, Hou JL, Lu KY, Chen LP, et al. Role of community-based active case finding in screening tuberculosis in Yunnan province of China. Infect Dis Poverty. 2019;8(1):1-12. 
Table 3: Baseline socio-demographic and clinical characteristics of adult pulmonary TB cases and controls at Temeke, Dar es Salaam

\begin{tabular}{|c|c|c|c|c|}
\hline Characteristics & $\begin{array}{l}\text { All, } \\
n=193(100 \%)\end{array}$ & $\begin{array}{l}\text { Controls, } \\
\text { n = } 94(48.7 \%)\end{array}$ & $\begin{array}{l}\text { TB cases, } \\
\mathrm{n}=99(51.3 \%)\end{array}$ & $P$-value \\
\hline Age, years, median (IQR) & $32.7(26.5-40)$ & $32.7(26.5-39.3)$ & $33(26-40)$ & $0.98^{\dagger \dagger}$ \\
\hline Sex, n (\%) & & & & $0.59^{\S}$ \\
\hline Female & $46(23.8)$ & $24(25.5)$ & $22(22.2)$ & \\
\hline Male & $147(76.2)$ & $70(74.5)$ & $77(77.8)$ & \\
\hline $\begin{array}{l}\text { BMI, } \mathrm{kg} / \mathrm{m}^{2}, \quad \text { median } \\
(\mathrm{IQR})\end{array}$ & $20.1(17.3-25.1)$ & $24.9(22.1-28.5)$ & $17.4(15.8-19.2)$ & $<0.001^{\dagger \dagger}$ \\
\hline BMI category, n (\%) & & & & $<0.001^{\S \S}$ \\
\hline Underweight & $73(37.8)$ & $6(6.38)$ & $67(67.68)$ & \\
\hline Normal weight & $71(36.8)$ & $41(43.62)$ & $30(30.30)$ & \\
\hline Overweight & $34(17.6)$ & $32(34.04)$ & $2(2.02)$ & \\
\hline Obese & $15(7.8)$ & $15(15.96)$ & - & \\
\hline Education, n (\%) & & & & $0.403^{\S \S}$ \\
\hline No formal education & $36(18.65)$ & $15(15.96)$ & $21(21.21)$ & \\
\hline Primary & $117(60.62)$ & $62(65.96)$ & $55(55.56)$ & \\
\hline Secondary & $31(16.06)$ & $12(12.77)$ & $19(19.19)$ & \\
\hline University & $9(4.66)$ & $5(5.32)$ & $4(4.04)$ & \\
\hline Occupation, n (\%) & & & & $0.031^{\S \S}$ \\
\hline Housewife & $14(7.29)$ & $5(5.38)$ & $9(9.09)$ & \\
\hline Unskilled labor & $17(8.85)$ & $7(7.53)$ & $10(10.10)$ & \\
\hline
\end{tabular}




\begin{tabular}{|c|c|c|c|c|}
\hline Semiskilled manual & $63(32.81)$ & $36(38.71)$ & $27(27.27)$ & \\
\hline $\begin{array}{l}\text { Semiskilled non- } \\
\text { manual }\end{array}$ & $76(39.58)$ & $32(34.41)$ & $44(44.44)$ & \\
\hline Student & $4(2.08)$ & - & $4(4.04)$ & \\
\hline Unemployed & $18(9.38)$ & $13(13.98)$ & $5(5.05)$ & \\
\hline Income $(\$)$, mean $\pm \mathrm{SD}$ & $85.99 \pm 73.53$ & $91.18 \pm 96.58$ & $81.07 \pm 41.12$ & $0.341^{\dagger}$ \\
\hline Cigarette smoking, n (\%) & $39(20.21)$ & $14(14.89)$ & $25(25.25)$ & $0.073^{\S}$ \\
\hline HIV infection, $\mathrm{n}(\%)$ & $24(12.44)$ & $11(11.70)$ & $13(13.13)$ & $0.48^{\S}$ \\
\hline Helminthiasis, n (\%) & $52(26.94)$ & $20(21.28)$ & $32(32.32)$ & $0.084^{\S}$ \\
\hline Strongyloidiasis & $31(16.06)$ & $9(9.57)$ & $22(22.22)$ & $0.019^{\S \S}$ \\
\hline Schistosomiasis & $11(5.70)$ & $5(5.32)$ & $6(6.06)$ & 1.0 \\
\hline \multicolumn{5}{|l|}{ URTI, n (\%) } \\
\hline Bacterial, $(n=124)$ & $58(46.77)$ & $18(62.07)$ & $40(42.11)$ & $0.059^{\S}$ \\
\hline Viral & $42(21.76)$ & $18(19.15)$ & $24(24.24)$ & $0.391^{\S}$ \\
\hline \multicolumn{5}{|l|}{ TB Symptoms, n (\%) } \\
\hline Night sweats & $108(55.96)$ & $12(12.77)$ & $96(96.97)$ & $<0.001^{\S \S}$ \\
\hline Fever & $111(57.51)$ & $17(18.09)$ & $94(94.95)$ & $<0.001^{\S \S}$ \\
\hline Cough & $145(75.13)$ & $46(48.94)$ & $99(100)$ & $<0.001^{\S \S}$ \\
\hline Weight loss & $114(59.07)$ & $15(15.96)$ & $99(100)$ & $<0.001^{\S \S}$ \\
\hline
\end{tabular}

$\mathrm{n}$, number; SD, standard deviation; IQR, Interquartile range; ${ }^{\dagger}$ Student $t$ test ${ }^{\dagger \dagger}$ Wilcoxon rank

471 sum test; ${ }^{\S}$ Pearson Chi-squared test; ${ }^{\S}$ Fisher's exact test; USD, United States Dollars (1 $472 \quad$ USD=2,171 Tanzanian Shillings, June 2016) 
Table 4: Distribution of haematological acute and chronic inflammatory markers and

disease status among TB cases and controls at Temeke, Dar es Salaam

\begin{tabular}{|c|c|c|c|c|}
\hline Serum parameters & $\begin{array}{l}\text { No. included* } \\
\text { Controls } \\
\text { Cases }\end{array}$ & $\begin{array}{l}\text { Controls, } \\
\mathrm{n}=94(48.7 \%)\end{array}$ & $\begin{array}{l}\text { TB cases, } \\
\mathrm{n}=99(51.3 \%)\end{array}$ & $P$-value \\
\hline Albumin, mean \pm SD & $94 / 99$ & $39.25 \pm 5.54$ & $28.58 \pm 6.14$ & $<0.001^{\dagger}$ \\
\hline $\begin{array}{l}\text { Ferritin, } \mu \mathrm{g} / \mathrm{L}, \\
\text { median }(\mathrm{IQR})\end{array}$ & $89 / 99$ & $103.5(59.5-159.5)$ & $355.3(162.2-642.7)$ & $<0.001^{\dagger \dagger}$ \\
\hline $\begin{array}{l}\text { sTfR, mg/L, mean } \pm \\
\text { SD }\end{array}$ & $75 / 89$ & $1.54 \pm 0.54$ & $1.92 \pm 0.74$ & $0.0003^{\dagger}$ \\
\hline $\begin{array}{l}\text { Transferrin, mean } \pm \\
\text { SD }\end{array}$ & $94 / 99$ & $2.52 \pm 0.48$ & $1.7 \pm 0.49$ & $<0.001^{\dagger}$ \\
\hline $\begin{array}{l}\text { CRP, mg/L, median } \\
(\mathrm{IQR})\end{array}$ & $94 / 99$ & $1.55(0.59-6)$ & $67.8(36.5-116.9)$ & $<0.001^{\dagger \dagger}$ \\
\hline $\begin{array}{l}\text { Neutrophil, median } \\
\text { (IQR) }\end{array}$ & $47 / 53$ & $2.29(1.47-3.23)$ & $5.07(3.85-6.86)$ & $<0.001^{\dagger \dagger}$ \\
\hline $\begin{array}{l}\text { Monocytes, median } \\
\text { (IQR) }\end{array}$ & $47 / 53$ & $0.47(0.31-0.66)$ & $0.94(0.67-1.26)$ & $<0.001^{\dagger \dagger}$ \\
\hline $\begin{array}{l}\text { Haemoglobin, } g / d L \\
\text { mean } \pm \mathrm{SD}\end{array}$ & $94 / 99$ & $12.8 \pm 2.1$ & $11.8 \pm 2.1$ & $0.001^{\dagger}$ \\
\hline $\begin{array}{l}\text { Thrombocytes, mean } \\
\pm \mathrm{SD}\end{array}$ & $94 / 99$ & $247.4 \pm 87.4$ & $363.6 \pm 124.2$ & $<0.001^{\dagger}$ \\
\hline Anaemia, n (\%) & $94 / 99$ & & & $0.001^{\S \S}$ \\
\hline
\end{tabular}




\begin{tabular}{|c|c|c|c|c|}
\hline No anaemia & & $52(55.32)$ & $28(28.28)$ & \\
\hline Mild anaemia & & $26(27.66)$ & $38(38.38)$ & \\
\hline $\begin{array}{l}\text { Moderate } \\
\text { anaemia }\end{array}$ & & $15(15.96)$ & $29(29.29$ & \\
\hline Severe anaemia & & $1(1.06)$ & $4(4.04)$ & \\
\hline $\begin{array}{l}\text { TB disease by CRP, } \\
\text { n }(\%)\end{array}$ & $94 / 99$ & & & $<0.001^{\S \S}$ \\
\hline No active disease & & $76(80.85)$ & $10(10.10)$ & \\
\hline Active disease & & $18(19.15)$ & $89(89.90)$ & \\
\hline $\begin{array}{l}\text { TB symptom } \\
\text { scoring, } \mathbf{n}(\%)\end{array}$ & $94 / 99$ & & & \\
\hline No TB & & $94(100.0)$ & - & \\
\hline $\begin{array}{l}\text { Mild } \quad \text { TB } \\
\text { symptoms }\end{array}$ & & - & $57(57.58)$ & \\
\hline $\begin{array}{l}\text { Severe } \mathrm{TB} \\
\text { symptoms }\end{array}$ & & - & $42(42.42)$ & \\
\hline
\end{tabular}

$\mathrm{n}$, number; SD, standard deviation; IQR, Interquartile range; ${ }^{\dagger}$ Student $t$ test, ${ }^{\dagger \dagger}$ Wilcoxon rank sum

477 test; ${ }^{\S}$ Pearson Chi-squared test; ${ }^{\S \S}$ Fisher's exact test; sTfR, soluble transferrin receptor; CRP, C-

478 reactive protein

$479{ }^{*}$ Participants with available inflammatory serum parameters 
Figures

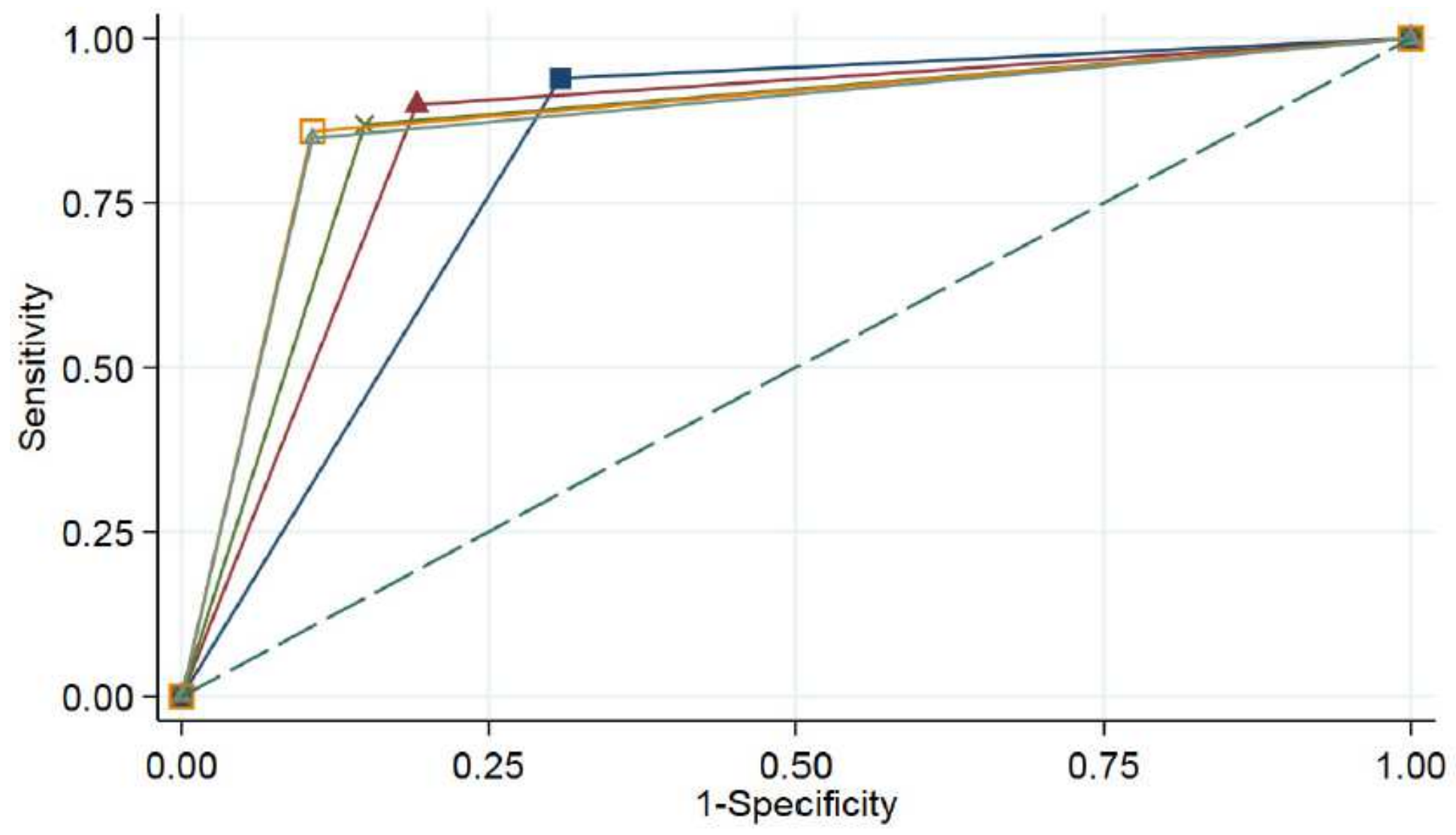

$\longrightarrow$ CRP $5 \mathrm{mg} / \mathrm{L}$ AUC: 0.8154

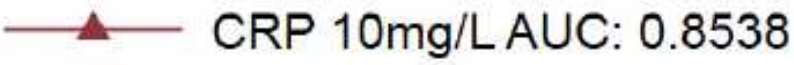

— CRP 15mg/L AUC: 0.859

$\square$ CRP 20mg/L AUC: 0.8761

$\longrightarrow$ CRP $25 \mathrm{mg} / \mathrm{L}$ AUC: 0.871

- - - Reference

Figure 1

Receiver operator characteristic (ROC) curves for different CRP cut-offs for TB diagnosis among adults in Temeke, Dar es Salaam. 


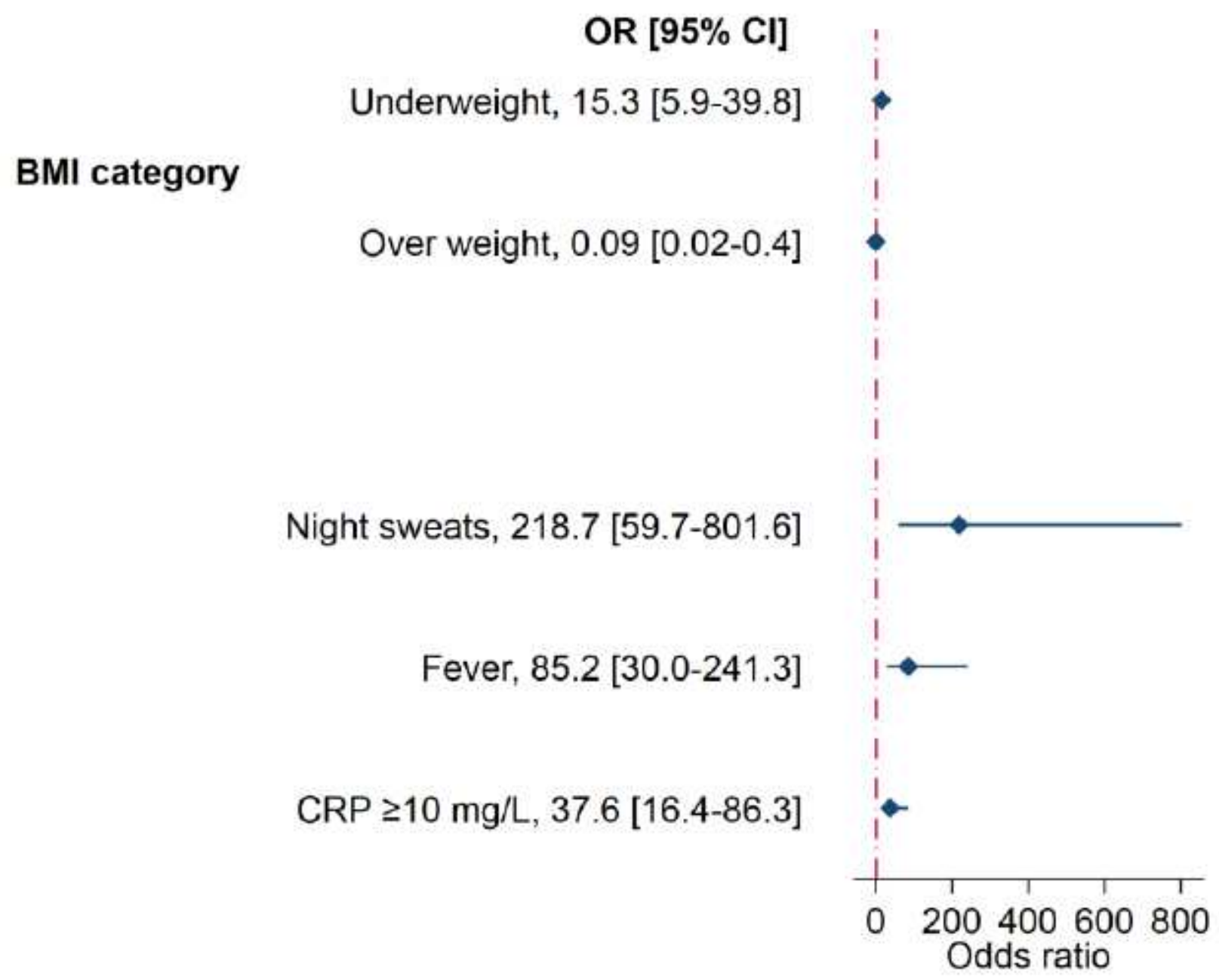

Figure 2

Univariate logistic regression analyses for CRP cut-off $\geq 10 \mathrm{mg} / \mathrm{L}$ and pulmonary TB symptoms 


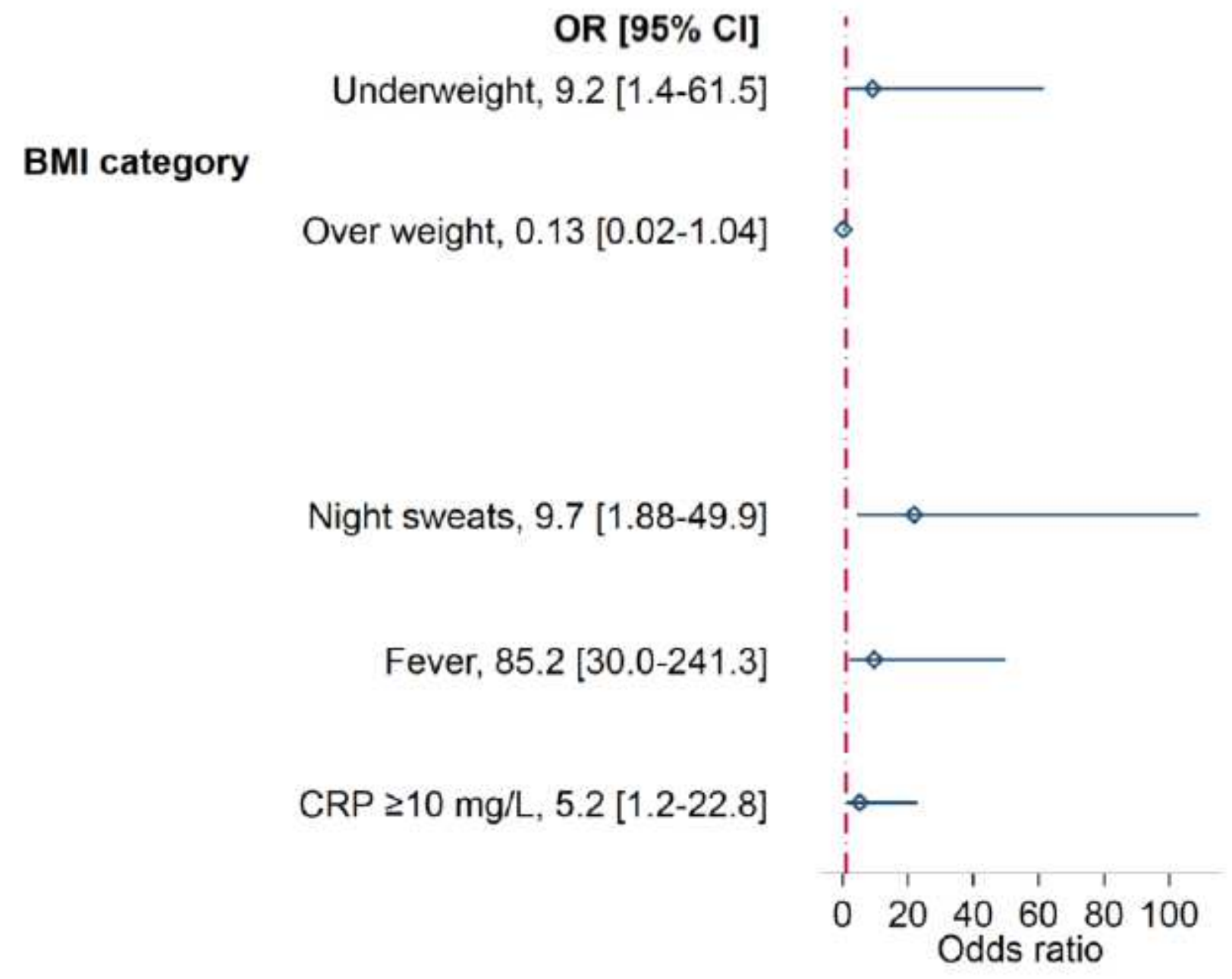

Figure 3

Multivariate logistic regression analyses for CRP cut-off $\geq 10 \mathrm{mg} / \mathrm{L}$ and TB symptoms 